\title{
Infections with Centrocestus armatus Metacercariae in Fishes from Water Systems of Major Rivers in Republic of Korea
}

\author{
Woon-Mok Sohn",*, Byoung-Kuk Na', Shin-Hyeong $\mathrm{Cho}^{2}$, Jung-Won $\mathrm{Ju}^{2}$, Cheon-Hyeon Kim³ ${ }^{3}$ Ki-Bok Yoon ${ }^{4}$, \\ Jai-Dong Kim ${ }^{5}$, Dong Cheol Son 6 , Soon-Won Lee \\ ${ }^{1}$ Department of Parasitology and Tropical Medicine, and Institute of Health Sciences, Gyeongsang National University College of Medicine, Jinju \\ 52727, Korea; 'Division of Vectors and Parasitic Diseases, Centers for Disease Control and Prevention, Osong 28159, Korea; ${ }^{3}$ Division of \\ Microorganism, Jeollabuk-do Institute of Health and Environment, Imsil 55928, Korea; ${ }^{4}$ Division of Microbiology, Jeollanam-do Institute of Health and \\ Environment, Muan 58568, Korea; ${ }^{5}$ Infectious Disease Examination Section, Chungcheongnam-do Institute of Health and Environment, Hongseong \\ 32254, Korea; ' Infectious Disease Research Section, Gyeongsangbuk-do Institute of Health and Environment, Youngcheon 38874, Korea; ${ }^{7}$ Infection \\ Disease Intelligence Division, Gangwon Institute of Health and Environment, Chuncheon 24203, Korea
}

\begin{abstract}
The infection status of Centrocestus armatus metacercariae (CaMc) was broadly surveyed in freshwater fishes from major river systems in the Republic of Korea (Korea) during 2008-2017. A total of 14,977 fishes was caught and examined by the artificial digestion method. CaMc were detected in 3,818 (97.1\%) (2,114 Z. platypus: $96.1 \%$ and 1,704 Z. temminckii: $98.4 \%)$ out of 3,932 Zacco spp. examined and their density was 1,867 (2,109 in Z. platypus and 1,567 in Z. temminckil) per fish infected. The prevalences with CaMc were high, 93.7-100\%, in Zacco spp. from all surveyed areas. However, their densities were more or less different by the surveyed areas and fish species. They were most high in Nakdong-gang in Gyeongsangnam-do (4,201 in average), and followed by Geum-gang (2,343), Nakdong-gang in Gyeongsangbuk-do (1,623), Han-gang (1,564), Tamjin-gang and Yeongsan-gang (1,540), streams in the east coast $(1,028)$, Seomjin-gang (488) and Mangyeong-gang (170). In another species of rasborinid fish, Opsariichthys uncirostris amurensis, CaMc were detected in $222(74.8 \%)$ out of 297 ones examined and their density was $278(1-4,480)$ per fish infected. CaMc were also detected in total 41 fish species except for the rasborinid fish, Z. platypus, Z. temminckii and O. uncirostris amurensis. Conclusively, it was confirmed that among the 3 species of rasborinid fish, Z. platypus and Z. temminckii are highly prevalent and $\mathrm{O}$. uncirostris amurensis is moderately prevalent with CaMc. Additionally, we could know that variety of fish species act as the second intermediate hosts of $C$. armatus in Korea.
\end{abstract}

Key words: Centrocestus armatus, Zacco platypus, Zacco temminckii, Opsariichthys uncirostris amurensis, metacercaria, river

\section{INTRODUCTION}

Centrocestus armatus (Digenea: Heterophyidae) is a small intestinal fluke bearing 42-48 circumoral spines, which mainly inhabits in the small intestines of birds and mammals. This fluke was first recovered from dogs, cats, rabbits, rats and mice experimentally fed with cyprinoid fish with $C$. armatus metacercariae (CaMc) in Japan [1]. Human infections were experimentally proven in Japan, and a natural human case was reported in the Republic of Korea (Korea) [1,2]. The freshwater snails, Semisul-

\footnotetext{
- Received 3 March 2018, revised 9 July 2018, accepted 12 July 2018.

*Corresponding author (wmsohn@gnu.ac.kr)

(C) 2018, Korean Society for Parasitology and Tropical Medicine

This is an Open Access article distributed under the terms of the Creative Commons

Attribution Non-Commercial License (http://creativecommons.org/licenses/by-nc/4.0)

which permits unrestricted non-commercial use, distribution, and reproduction in any

medium, provided the original work is properly cited.
}

cospira spp., are known to be the first intermediate hosts in Japan and Korea $[3,4]$. Various species of freshwater fish, including Zacco platypus and Z. temminckii, were reported as the second intermediate hosts in Japan and Korea [5-13]. As the natural definitive hosts of this fluke, the large egret, Egretta alba modesta, and stray cat, Felis catus, were recorded in Korea [14-17].

This species of heterophyid fluke is not clinically important unlike Clonorchis sinensis and Metagonimus spp. as fishborne zoonotic trematodes. And so the epidemiological study on the metacercarial infections in fish hosts has been rarely done in Korea [6-8,10,11]. In Korea, Chun [6] described more than 11 species of digenetic trematode metacercariae (DTM) together with CaMc detected in 16 fish species from streams and ponds in adjacent areas of Nakdong-gang. Rhee et al. [8] detected CaMc in 7 out of 32 fish species from Mangyeong-gang and they also found them in 5 out of 33 fish species from Dongjin- 
gang [9]. In 1988, Hong et al. [10] investigated the infection status of CaMc in 2 species of chub, Z. platypus and Z. temminckii, collected from 19 sites in 6 major rivers of Korea. Recently, Cho et al. [12] reported the infection status of zoonotic trematode metacercariae including CaMc in fishes from the water systems in Gangwon-do. Sohn et al. [13] surveyed the infection status of DTM in fishes from the water systems of Hantan-gang and Imjin-gang. However, most of previous studies were performed in limited areas except for Hong et al. [10]. Even in Hong et al. [10], only 2 species of chub, Z. platypus and Z. temminckii, collected from 19 sites were examined. Therefore, the present study was performed to estimate the endemisities of CaMc in the freshwater fishes nationwidely and moreover, to expand the fauna on the fish hosts of $C$. armatus in Korea.

\section{MATERIALS AND METHODS}

\section{Fish collected from water systems of Han-gang}

Fishes from Hantan-gang in Cheorwon-gun (2010: 177 fishes in 15 spp.; 2012: 255 fishes in 18 spp.; 2013: 200 fishes in 23 spp.; 2014: 400 fishes in 15 spp.), Suipcheon in Yanggugun (2009: 196 fishes in 14 spp.), Hongcheon-gang in Hongcheon-gun (2010: 186 fishes in 14 spp.), Pyeongchang-gang in Pyeongchang-gun (2013: 230 fishes in 15 spp.), Dong-gang in Yeongwol-gun (2009: 251 fishes in 19 spp.), Seom-gang in Hoengseong-gun (2011: 184 fishes in 20 spp.) and Choyanggang in Jeongseon-gun (2012: 196 fishes in 15 spp.), Gangwon-do, and Dalcheon in Goesan-gun (2011: 99 fishes in 12 spp.), Chungcheongbuk-do were examined.

\section{Fish collected from water systems of Geum-gang}

Fishes from Chogangcheon in Yeongdong-gun (2011: 132 fishes in 15 spp.), Chungcheongbuk-do, Cheonnae-gang in Geumsan-gun (2011: 140 fishes in 20 spp.; 2013: 146 fishes in 13 spp.; 2014: 161 fishes in 17 spp.; 2015: 79 fishes in 14 spp.), Yugucheon in Gongju-si (2013: 146 fishes in 11 spp.; 2015: 165 fishes in 11 spp.) and Jicheon in Cheongyang-gun (2014: 89 fishes in 13 spp.), Chungcheongnam-do, Jujacheon in Jinangun (2012: 208 fishes in 19 spp.) and Namdaecheon in Mujugun (2012: 123 fishes in 14 spp.), Jeollabuk-do were examined.

\section{Fish collected from water systems of Mangyeong-gang and Dongjin-gang}

Fishes from Soyangcheon in Wanju-gun (2012: 82 fishes in 8 spp.; 2013: 97 fishes in 12 spp.; 2014: 165 fishes in 9 spp.;
2015: 200 fishes in 12 spp.) and Jungeupcheon in Jungeup-si (2013: 88 fishes in 11 spp.), Jeollabuk-do were examined.

Fish collected from water systems of Yeongsan-gang and Tamjin-gang

Fishes from Hwangryong-gang in Jangseong-gun (2011: 107 fishes in 14 spp.), Jiseokcheon in Hwasun-gun (2011: 54 fishes in 8 spp.) and Naju-si (2013: 86 fishes in 9 spp.), Yeongamcheon in Yeongam-gun (2013: 45 fishes in 8 spp.;), Tamjingang in Jangheung-gun (2014: 167 fishes in 13 spp.; 2015: 243 fishes in 15 spp.; 2016: 302 fishes in 16 spp.; 2017: 420 fishes in 19 spp.) and Gangjin-gum (2014: 110 fishes in 12 spp.; 2017: 407 fishes in 15 spp.), Jeollanam-do were examined.

\section{Fish collected from water systems of Seomjin-gang}

Fishes from Osucheon in Imsil-gun (2011: 105 fishes in 10 spp.; 2012: 190 fishes in 10 spp.; 2013: 46 fishes in 5 spp.), Seomjin-gang in Sunchang-gun (2014: 69 fishes in 22 spp.; 2015: 241 fishes in 23 spp.) and Songdaecheon in Namwon-si (2012: 139 fishes in 12 spp.; 2013: 57 fishes in 7 spp.), Jeollabuk-do, Seomjin-gang in Gokseong-gun (2015: 146 fishes in 11 spp.) and in Gurye-gun (2014: 183 fishes in 21 spp.), Jeollanam-do, Hoengcheon (2014: 156 fishes in 13 spp.), Namsancheon (2015 and 2016: 234 fishes in 12 spp.) and Jugyocheon (2011: 54 fishes in 14 spp.) in Hadong-gun, Gyeongsangnamdo were examined.

\section{Fish collected from water systems of Nakdong-gang in Gyeongsangnam-do}

Fishes from Yangcheon in Sancheong-gun (2010: 350 fishes in 15 spp.; 2011: 201 fishes in 14 spp.; 2012: 221 fishes in 11 spp.; 2013: 644 fishes in 20 spp.; 2014: 291 fishes in 14 spp.; 2015: 183 fishes in 15 spp.; 2016: 253 fishes in 16 spp.; 2017 : 408 fishes in 22 spp.), Jisucheon in Jinju-si (2014: 94 fishes in 11 spp.) and Hamancheon in Haman-gun (2014: 73 fishes in 9 spp.) were examined.

\section{Fish collected from water systems of Nakdong-gang in Gyeongsangbuk-do}

Fishes from Naeseongcheon in Bonghwa-gun (2008: 97 fishes in 12 spp.) and Yecheon-gun (2008: 131 fishes in 18 spp.; 2014: 103 fishes in 15 spp.), Nakdong-gang in Andong-si (2008: 118 fishes in 12 spp.; 2009: 56 fishes in 11 spp.), Yeong-gang in Mungyeong-si (2009: 108 fishes in 15 spp.), Banbyeoncheon in Yeongyang-gun (2008: 86 fishes in 12 spp.; 2015: 161 fishes 

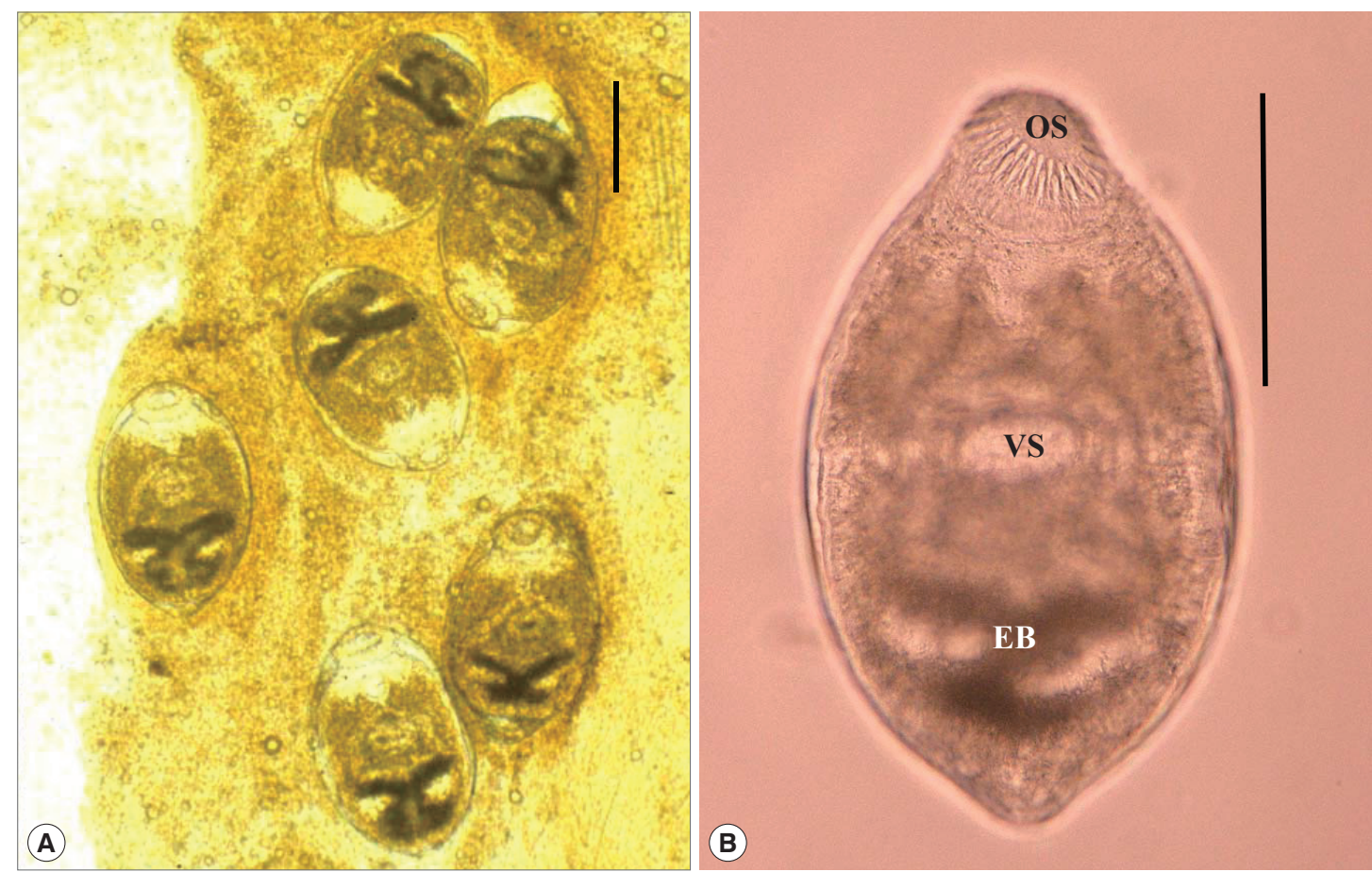

Fig. 1. Metacercariae of Centrocestus armatus encysted in the viscera of a pale chub, Zacco platypus (A) and an isolated one (B). They are characterized by long elliptical shape, 0.20-0.25 $\times 0.10-0.12 \mathrm{~mm}$ in size, providing 42 circumoral spines around oral sucker (OS) arranged 2 rows, a ventral sucker (VS) in the median and X-shaped excretory bladder (EB). Scale bar is $0.1 \mathrm{~mm}$.

in 12 spp.), Namdaecheon in Uiseong-gun (2009: 83 fishes in 9 spp.), Wicheon in Gunwi-gun (2008: 136 fishes in 16 spp.; 2011: 105 fishes in 13 spp.; 2013: 107 fishes in 12 spp.; 2014: 338 fishes in 24 spp.; 2015: 245 fishes in 19 spp.; 2016: 279 fishes in 24 spp.; 2017: 199 fishes in 17 spp.), Bukcheon in Sangju-si (2008: 45 fishes in 11 spp.), Hoecheon in Goryeonggun (2013: 165 fishes in 13 spp.), Nakdong-gang in Dalseonggun (2009: 63 fishes in 5 spp.) and Baekcheon in Seongju-gun (2009: 71 fishes in 12 spp.) were examined.

\section{Fish collected from water systems in the east coast of Korea}

Fishes from Namdaecheon in Yangyang-gun (2009: 174 fishes in 11 spp.; 2015: 140 fishes in 13 spp.), Osipcheon (2009: 155 fishes in 11 spp.; 2015: 143 fishes in 15 spp.) and Gagokcheon (2009: 109 fishes in 8 spp.) in Samcheok-si, Gangwon-do, Osipcheon in Yeongdeok-gun (2008: 104 fishes in 9 spp.; 2015: 122 fishes in 11 spp.), Wangpicheon in Uljin-gun (2015: 239 fishes in 13 spp.) and Hyeongsan-gang in Gyeongju-si (2015: 111 fishes in 12 spp.), Gyeongsangbuk-do, Cheokgwacheon (2015: 221 fishes in 10 spp.) and Taehwa-gang (2015: 89 fishes in 14 spp.) in Ulju-gun, Ulsan Metropolitan City were examined.

\section{Examination methods}

All collected fishes with ice were transferred to the laboratory of the Department of Parasitology and Tropical Medicine, Gyeongsang National University College of Medicine, Jinju, Korea. After the identification of fish species, they were individually ground with a mortar or grinder. Each ground fish meat was mixed with artificial gastric juice and the mixture was incubated at $36^{\circ} \mathrm{C}$ for $2 \mathrm{hr}$. The digested material was filtered through $1 \times 1$ $\mathrm{mm}$ of mesh, and washed with $0.85 \%$ saline untill the supernatant is clear. The sediment was carefully examined under a stereomicroscope. CaMc were separately collected by the general feature [11] (Fig. 1), counted and calculated for infection rates (\%) and densities (No. of CaMc per fish infected) by fish species.

\section{RESULTS}

Infection status with CaMc in Zacco spp. from Han-gang

The metacercariae of $C$. armatus (CaMc) were detected in 553 (99.3\%) Zacco spp. (253 Z. platypus: $99.6 \%$ and 300 Z. temminckii: $99.0 \%)$ and their average density was 1,564 (1,904 in Z. platypus and 1,278 in Z. temminckii) per fish infected. The infection status with CaMc by the surveyed areas was detailed in Table 1 . 


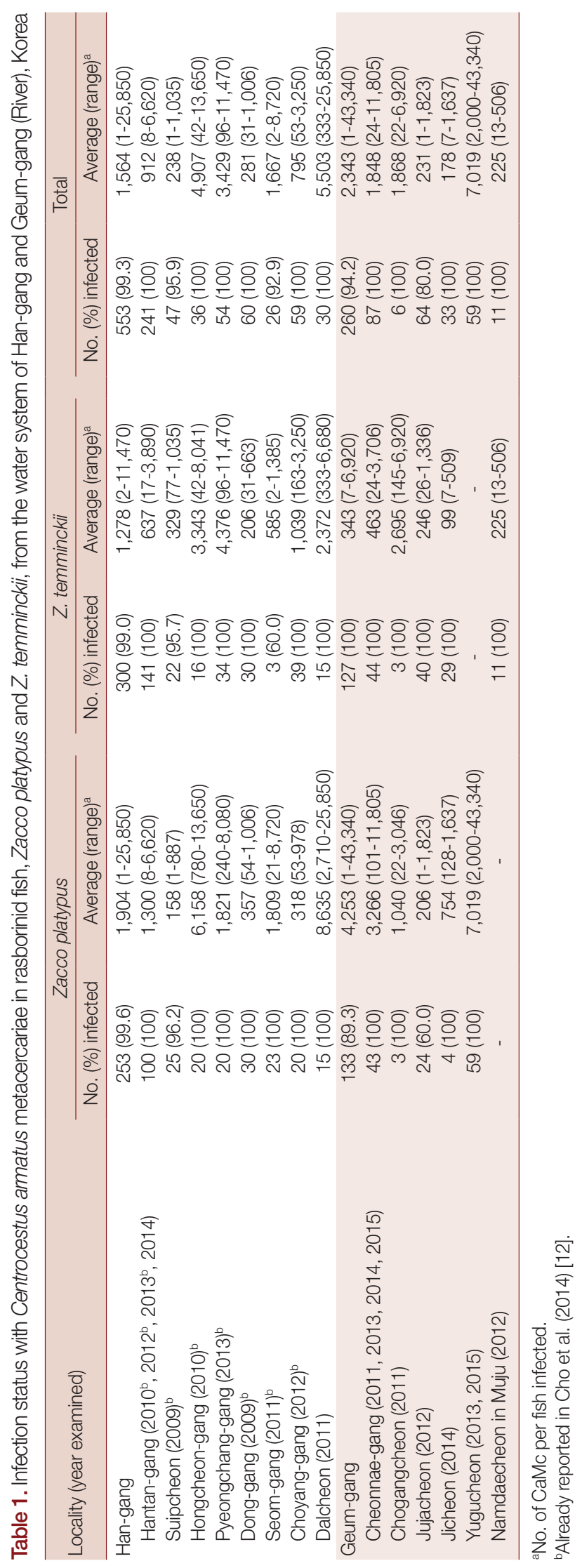

Infection status with CaMc in Zacco spp. from Geum-gang

CaMc were detected in 260 (94.2\%) Zacco spp. (133 Z. platypus: $89.3 \%$ and 127 Z. temminckii: $100 \%$ ) and their average density was 2,343 (4,253 in Z. platypus and 343 in Z. temminckii) per fish infected. The infection status with CaMc by the surveyed areas was detailedly revealed in Table 1.

Infection status with CaMc in Zacco spp. from Mangyeonggang and Dongjin-gang

CaMc were detected in 136 (98.6\%) Zacco spp. (56 Z. platypus: $96.6 \%$ and 80 Z. temminckii: $100 \%$ ) and their average density was 170 (137 in Z. platypus and 193 in Z. temminckii) per fish infected. The infection status with CaMc by the surveyed areas was detailed in Table 2.

\section{Infection status with CaMc in Zacco spp. from Yeongsan- gang}

CaMc were detected in 84 (100\%) Zacco spp. (80 Z. platypus and 4 Z. temminckii) and their average density was $1,493(1,403$ in Z. platypus and 3,290 in Z. temminckii) per fish infected. The infection status with CaMc by the surveyed areas was detailedly revealed in Table 2.

Infection status with CaMc in Zacco spp. from Tamjin-gang

CaMc were detected in 391 (100\%) Zacco spp. (213 Z. platypus and $178 \mathrm{Z}$. temminckii) and their average density was 1,550 $(1,970$ in Z. platypus and 1,048 in Z. temminckii) per fish infected. The infection status with CaMc by the surveyed areas was detailed in Table 2.

\section{Infection status with CaMc in Zacco spp. from Seomjin-gang}

CaMc were detected in 531 (99.4\%) Zacco spp. (311 Z. platypus: $99.7 \%$ and $220 \mathrm{Z}$. temminckii: $99.1 \%$ ) and their average density was 488 (596 in Z. platypus and 336 in Z. temminckii) per fish infected. The infection status with CaMc by the surveyed areas was detailedly shown in Table 2 .

\section{Infection status with CaMc in Zacco spp. from Nakdong-} gang in Gyeongsangnam-do

CaMc were detected in 713 (100\%) Zacco spp. (323 Z. platypus and 390 Z. temminckii) and their average density was 4,201 (4,383 in Z. platypus and 4,050 in Z. temminckii) per fish infected. The infection status with CaMc by the surveyed areas was detailed in Table 3. 
Table 2. Infection status with CaMc in rasborinid fish, Zacco platypus and Z. temminckii, from the water systems in the western and southern regions of Korea

\begin{tabular}{|c|c|c|c|c|c|c|}
\hline \multirow[b]{2}{*}{ Locality (year examined) } & \multicolumn{2}{|c|}{ Zacco platypus } & \multicolumn{2}{|c|}{ Z. temminckii } & \multicolumn{2}{|r|}{ Total } \\
\hline & $\begin{array}{l}\text { No. (\%) } \\
\text { infected }\end{array}$ & $\begin{array}{l}\text { Average } \\
\text { (range) }^{\mathrm{a}}\end{array}$ & $\begin{array}{l}\text { No. (\%) } \\
\text { infected }\end{array}$ & $\begin{array}{l}\text { Average } \\
\text { (range) }^{\mathrm{a}}\end{array}$ & $\begin{array}{l}\text { No. (\%) } \\
\text { infected }\end{array}$ & $\begin{array}{l}\text { Average } \\
\text { (range) }^{\mathrm{a}}\end{array}$ \\
\hline Mangyeong-gang ${ }^{b}$ & 56 (96.6) & $137(1-1,148)$ & $80(100)$ & $193(1-2,536)$ & $136(98.6)$ & $170(1-2,536)$ \\
\hline Soyangcheon (2012-2015) & $28(100)$ & $259(13-1,148)$ & $80(100)$ & $193(1-2,536)$ & $108(100)$ & $210(1-2,536)$ \\
\hline Jungeupcheon $(2013)^{b}$ & 28 (93.3) & $16(1-85)$ & - & - & 28 (93.3) & $16(1-85)$ \\
\hline Yeongsan-gang & $80(100)$ & $1,403(5-19,200)$ & $4(100)$ & $3,290(123-7,200)$ & $84(100)$ & $1,493(5-19,200)$ \\
\hline Hwangryong-gang (2011) & $15(100)$ & $289(34-814)$ & - & - & $15(100)$ & $289(34-814)$ \\
\hline Jiseokcheon $(2011,2013)$ & $50(100)$ & $45(5-399)$ & - & - & $50(100)$ & $45(5-399)$ \\
\hline Yeongamcheon (2013) & $15(100)$ & $7,042(420-19,200)$ & $4(100)$ & $3,290(123-7,200)$ & $19(100)$ & $6,252(123-19,200)$ \\
\hline Tamjin-gang & $213(100)$ & $1,970(11-13,420)$ & $178(100)$ & $1,048(12-7,120)$ & $391(100)$ & $1,550(11-13,420)$ \\
\hline In Jangheung (2014-2017) & $138(100)$ & $2,711(11-13,420)$ & $152(100)$ & $1,113(12-7,120)$ & $290(100)$ & $1,873(11-13,420)$ \\
\hline In Gangjin $(2014,2017)$ & $75(100)$ & $607(42-2,661)$ & $26(100)$ & $665(16-2,787)$ & $101(100)$ & $622(16-2,787)$ \\
\hline Seomjin-gang & $311(99.7)$ & $596(6-7,440)$ & $220(99.1)$ & $336(1-4,300)$ & $531(99.4)$ & $488(1-7,440)$ \\
\hline Osucheon $(2011,2012,2013)$ & 99 (99.0) & $213(17-2,125)$ & - & - & $99(99.0)$ & $213(17-2,125)$ \\
\hline In Sunchang $(2014,2015)$ & $51(100)$ & $798(14-4,480)$ & $15(100)$ & $17(4-48)$ & $66(100)$ & $621(4-4,480)$ \\
\hline Songdaecheon $(2012,2013)$ & $46(100)$ & $336(6-3,620)$ & $57(100)$ & $716(3-4,300)$ & $103(100)$ & $547(3-4,300)$ \\
\hline In Gokseong (2015) & $16(100)$ & $814(99-1,985)$ & $37(97.4)$ & $244(1-2,540)$ & $53(98.2)$ & $416(1-2,540)$ \\
\hline In Gurye (2014) & $24(100)$ & $1,024(37-5,429)$ & $13(92.9)$ & $77(2-710)$ & $37(97.4)$ & $691(2-5,429)$ \\
\hline Hoengcheon (2014) & $14(100)$ & $736(20-2,615)$ & $25(100)$ & $137(4-394)$ & $39(100)$ & $352(4-2,615)$ \\
\hline Namsancheon $(2015,2016)$ & $41(100)$ & $1,072(83-7,440)$ & $68(100)$ & $277(5-3,005)$ & $109(100)$ & $576(5-7,440)$ \\
\hline Jugyocheon (2011) & $20(100)$ & $804(123-2,245)$ & $5(100)$ & $123(11-205)$ & $25(100)$ & $668(11-2,245)$ \\
\hline
\end{tabular}

${ }^{a}$ No. of CaMc per fish infected.

${ }^{b}+$ Dongjin-gang.

Table 3. Infection status with CaMc in rasborinid fish, Zacco platypus and Z. temminckii, from the water system of Nakdong-gang (River) in Korea

\begin{tabular}{|c|c|c|c|c|c|c|}
\hline \multirow[b]{2}{*}{ Locality (year examined) } & \multicolumn{2}{|c|}{ Zacco platypus } & \multicolumn{2}{|c|}{ Z. temminckii } & \multicolumn{2}{|r|}{ Total } \\
\hline & $\begin{array}{l}\text { No. (\%) } \\
\text { infected }\end{array}$ & $\begin{array}{l}\text { Average } \\
\text { (range) }^{\mathrm{a}}\end{array}$ & $\begin{array}{l}\text { No. (\%) } \\
\text { infected }\end{array}$ & $\begin{array}{l}\text { Average } \\
\text { (range) }^{a}\end{array}$ & $\begin{array}{l}\text { No. (\%) } \\
\text { infected }\end{array}$ & $\begin{array}{l}\text { Average } \\
\text { (range) }^{\mathrm{a}}\end{array}$ \\
\hline Nakdong-gang ${ }^{b}$ & $323(100)$ & $4,383(2-30,500)$ & $390(100)$ & $4,050(55-41,460)$ & $713(100)$ & $4,201(2-41,460)$ \\
\hline Yangcheon (2010-2017) & $279(100)$ & $4,669(6-30,500)$ & $360(100)$ & $4,262(55-41,460)$ & $639(100)$ & $4,440(6-41,460)$ \\
\hline Jisucheon (2014) & $35(100)$ & $3,186(25-12,400)$ & $5(100)$ & $3,527(560-13,260)$ & $40(100)$ & $3,228(25-13,260)$ \\
\hline Hamancheon (2014) & $9(100)$ & $156(2-318)$ & $25(100)$ & $1,108(295-3,376)$ & $34(100)$ & $856(2-3,376)$ \\
\hline Nakdong-gang ${ }^{c}$ & $542(91.1)$ & $2,026(1-24,190)$ & $236(95.6)$ & $699(1-10,501)$ & $778(92.4)$ & $1,623(1-24,190)$ \\
\hline Wicheon $(2008,2011,2013-2017)$ & $329(100)$ & $2,961(15-24,190)$ & $163(99.4)$ & $901(7-10,501)$ & $492(99.8)$ & $2,279(7-24,190)$ \\
\hline Naeseongcheon in Bonghwa (2008) & $4(36.4)$ & $14(1-50)$ & $6(85.7)$ & $16(1-44)$ & $10(55.6)$ & $15(1-50)$ \\
\hline Banbyeoncheon $(2008,2015)$ & $58(100)$ & $1,793(3-6,290)$ & $37(97.4)$ & $408(10-1,170)$ & $95(99.0)$ & $1,254(3-6,290)$ \\
\hline In Andong $(2008,2009)$ & $44(95.7)$ & $305(3-1,985)$ & $24(96.0)$ & $122(16-352)$ & $68(95.8)$ & $240(3-1,985)$ \\
\hline Hoecheon (2013) & $21(60.0)$ & $4(1-10)$ & $6(46.2)$ & $6(1-20)$ & 27 (56.3) & $4(1-20)$ \\
\hline Naeseongcheon in Yecheon $(2008,2014)$ & 45 (88.2) & $117(1-786)$ & - & - & 45 (88.2) & $117(1-786)$ \\
\hline Yeong-gang (2009) & $19(95.0)$ & $38(3-123)$ & - & - & $19(95.0)$ & $38(3-123)$ \\
\hline Namdaecheon in Uiseong (2009) & $15(100)$ & $17(8-33)$ & - & - & $15(100)$ & $17(8-33)$ \\
\hline Baekcheon (2009) & $5(33.3)$ & $14(1-61)$ & - & - & 5 (33.3) & $14(1-61)$ \\
\hline In Dalseong (2009) & $2(13.3)$ & $3(1-5)$ & - & - & $2(13.3)$ & $3(1-5)$ \\
\hline
\end{tabular}

${ }^{a}$ No. of CaMc per fish infected.

bin Gyeongsangnam-do.

in Gyeongsangbuk-do.

\section{Infection status with CaMc in Zacco spp. from Nakdong- gang in Gyeongsangbuk-do}

CaMc were detected in 778 (92.4\%) Zacco spp. (542 Z. platypus: $91.1 \%$ and 236 Z. temminckii: $95.6 \%$ ) and their average density was 1,623 (2,026 in Z. platypus and 699 in Z. temminckii) per fish infected. The infection status with CaMc by the surveyed areas was detailedly revealed in Table 3. 
Table 4. Infection status with CaMc in rasborinid fish, Zacco platypus and Z. temminckii, from the water systems in the east coast of Korea

\begin{tabular}{|c|c|c|c|c|c|c|}
\hline \multirow[b]{2}{*}{ Locality (year examined) } & \multicolumn{2}{|c|}{ Zacco platypus } & \multicolumn{2}{|c|}{ Z. temminckii } & \multicolumn{2}{|r|}{ Total } \\
\hline & $\begin{array}{l}\text { No. (\%) } \\
\text { infected }\end{array}$ & $\begin{array}{l}\text { Average } \\
\text { (range) }^{a}\end{array}$ & $\begin{array}{l}\text { No. (\%) } \\
\text { infected }\end{array}$ & $\begin{array}{l}\text { Average } \\
\text { (range) }^{a}\end{array}$ & $\begin{array}{l}\text { No. (\%) } \\
\text { infected }\end{array}$ & $\begin{array}{l}\text { Average } \\
\text { (range) }^{a}\end{array}$ \\
\hline Namdaecheon in Yangyang $\left(2009^{b}, 2015\right)$ & $28(84.8)$ & $207(2-1,561)$ & $56(86.2)$ & $1,530(1-14,419)$ & $84(85.7)$ & $1.089(1-14,419)$ \\
\hline Osipcheon in Samcheok $\left(2009^{b}, 2015\right)$ & $37(97.4)$ & $454(9-4,925)$ & - & - & $37(97.4)$ & $454(9-4,925)$ \\
\hline Gagokcheon (2009) ${ }^{b}$ & $18(94.7)$ & $469(1-1,880)$ & $12(80.0)$ & $202(1-1,518)$ & $30(88.2)$ & $362(1-1,880)$ \\
\hline Wangpicheon (2015) & $30(100)$ & $1,412(46-5,300)$ & $15(100)$ & $3,079(371-6,904)$ & $45(100)$ & $1,967(46-6,904)$ \\
\hline Osipcheon in Yeongdeok $(2008,2015)$ & $58(98.3)$ & $1,121(2-5,320)$ & $2(100)$ & $848(310-1,385)$ & $60(98.4)$ & $1,112(2-5,320)$ \\
\hline Hyeongsan-gang (2015) & $8(100)$ & $2,613(195-7,650)$ & $33(100)$ & $806(88-5,833)$ & $41(100)$ & $1,158(88-7,650)$ \\
\hline Cheokgwacheon (2015) & $15(100)$ & $895(76-2,670)$ & $50(100)$ & $940(57-4,236)$ & $65(100)$ & $929(57-4,236)$ \\
\hline Taehwa-gang (2015) & $9(64.3)$ & $5(1-31)$ & $1(100)$ & 72 & $10(66.7)$ & $12(1-72)$ \\
\hline Total & $203(94.0)$ & $851(1-7,650)$ & $169(93.4)$ & $1,240(1-14,419)$ & $372(93.7)$ & $1,028(1-14,419)$ \\
\hline
\end{tabular}

${ }^{a}$ No. of CaMc per fish infected.

${ }^{\text {b} A l r e a d y ~ r e p o r t e d ~ i n ~ C h o ~ e t ~ a l . ~(2014) ~[12] . ~}$

Table 5. Overall infection status with CaMc in rasborinid fish, Zacco platypus and Z. temminckii, by the water systems of Korea

\begin{tabular}{|c|c|c|c|c|c|c|}
\hline \multirow[b]{2}{*}{ Locality (river) } & \multicolumn{2}{|c|}{ Zacco platypus ${ }^{a}$} & \multicolumn{2}{|c|}{ Z. temminckilia } & \multicolumn{2}{|c|}{ Total } \\
\hline & $\begin{array}{l}\text { No. (\%) } \\
\text { infected }\end{array}$ & $\begin{array}{l}\text { Average } \\
\text { (range) }^{e}\end{array}$ & $\begin{array}{l}\text { No. (\%) } \\
\text { infected }\end{array}$ & $\begin{array}{l}\text { Average } \\
\text { (range) }^{\mathrm{e}}\end{array}$ & $\begin{array}{l}\text { No. (\%) } \\
\text { infected }\end{array}$ & $\begin{array}{l}\text { Average } \\
{(\text { range })^{e}}^{e}\end{array}$ \\
\hline Han-gang & $253(99.6)$ & $1,904(1-25,850)$ & $300(99.0)$ & $1,278(2-11,470)$ & 553 (99.3) & $1,564(1-25,850)$ \\
\hline Geum-gang & $133(89.3)$ & $4,253(1-43,340)$ & $127(100)$ & $343(7-6,920)$ & $260(94.2)$ & $2,343(1-43,340)$ \\
\hline Mangyeong-gang ${ }^{b}$ & $56(96.6)$ & $137(1-1,148)$ & $80(100)$ & $193(1-2,536)$ & $136(98.6)$ & $170(1-2,536)$ \\
\hline Yeongsan-gang & $80(100)$ & $1,403(5-19,200)$ & $4(100)$ & $3,290(123-7,200)$ & $84(100)$ & $1,493(5-19,200)$ \\
\hline Tamjin-gan & $213(100)$ & $1,970(11-13,420)$ & $178(100)$ & $1,048(12-7,120)$ & $391(100)$ & $1,550(11-13,420)$ \\
\hline Seomjin-gang & $311(99.7)$ & $596(6-7,440)$ & $220(99.1)$ & $336(1-4,300)$ & $531(99.4)$ & $488(1-7,440)$ \\
\hline Nakdong-gang ${ }^{c}$ & $323(100)$ & $4,383(2-30,500)$ & $390(100)$ & $4,050(55-41,460)$ & $713(100)$ & $4,201(2-41,460)$ \\
\hline Nakdong-gang ${ }^{d}$ & $542(91.1)$ & $2,026(1-24,190)$ & $236(95.6)$ & $699(1-10,501)$ & $778(92.4)$ & $1,623(1-24,190)$ \\
\hline Streams in the east coast & $203(94.0)$ & $851(1-7,650)$ & $169(93.4)$ & $1,240(1-14,419)$ & $372(93.7)$ & $1,028(1-14,419)$ \\
\hline Total & $2,114(96.1)$ & $2,109(1-43,340)$ & $1,704(98.4)$ & $1,567(1-41,460)$ & $3,818(97.1)$ & $1,867(1-43,340)$ \\
\hline
\end{tabular}

aTotal 2,200 Z. platypus and 1,732 Z. temminckii were examined.

bSoyangcheon and Jungeupcheon (a stream of Dongjingang).

in Gyeongsangnam-do.

in Gyeongsangbuk-do.

eNo. of CaMc per fish infected.

Infection status with CaMc in Zacco spp. from the streams in the east coast of Korea

CaMc were detected in 372 (93.7\%) Zacco spp. (203 Z. platypus: $94.0 \%$ and 169 Z. temminckii: 93.4\%) and their average density was 1,028 (851 in Z. platypus and 1,240 in Z. temminckii) per fish infected. The infection status with CaMc by the surveyed areas was detailed in Table 4.

\section{Overall infection status with CaMc in Zacco spp. by the water systems of Korea}

CaMc were detected in 3,818 (97.1\%) (2,114 Z. platypus: $96.1 \%$ and 1,704 Z. temminckii: $98.4 \%$ ) out of 3,932 Zacco spp. examined and their density was 1,867 (2,109 in Z. platy- pus and 1,567 in Z. temminckii) per fish infected. The prevalences with CaMc were high, 93.7-100\%, in Zacco spp. from all surveyed areas. Their densities were more or less different by the surveyed areas and fish species. The infection status with CaMc by the surveyed areas was detailedly revealed in Table 5 .

\section{Infection status with CaMc in Opsariichthys uncirostris amurensis from the water systems of Korea}

CaMc were detected in 222 (74.8\%) out of 297 O. uncirostris amurensis examined and their density was 1-4,480 (278 in average) per fish infected. The infection status with CaMc by the surveyed areas was detailedly shown in Supplementary Table S1. 


\section{Fish species with CaMc except for the rasborinid fish}

CaMc were also detected in total 41 fish species except for the rasborinid fish, $Z$. platypus, Z. temminckii and $O$. uncirostris amurensis. Fish species with CaMc by the surveyed areas (year examined) were detailedly designated in Supplementary Table S2.

\section{DISCUSSION}

In the present study, we investigated the infection status with CaMc nationwidely in the freshwater fishes from the water systems of major rivers in Korea. Total 89 times in 50 sites (Han-gang: 11 times in 8 sites; Geum-gang: 10 times in 6 sites; Mangyeong-gang and Dongiin-gang: 5 times in 2 sites; Yeongsan-gang and Tamjin-gang: 10 times in 5 sites; Seomjin-gang: 13 times in 8 sites; Nakdong-gang: 29 times in 13 sites; streams in the east coast: 11 times in 8 sites) were surveyed. However, the data from the 12 times surveys performed in 10 sites (Hangang: 9 times in 7 sites; streams in the east coast: 3 times in 3 sites) were already reported in Cho et al. [12]. At any rate, total 14,977 fish including 2,200 Z. platypus, 1,732 Z. temminckii and 297 O. uncirostris amurensis were examined in this study. The proportion of Zacco spp. is more or less different by the surveyed sites (19.8-33.0\%: 26.3\% in average) and fish species (Z. platypus: 9.2-22.1\%; Z. temminckii: 9.1-14.4\%). These differences are due to the fish ecology in surveyed rivers.

The prevalences with CaMc were very high, 93.7-100\% (97.1\% in average), in Zacco spp. from all surveyed sites. However, their densities were more or less different by the surveyed areas, and slightly higher in Z. platypus (2,109 in average) than in Z. temminckii $(1,567)$. They were most high in Nakdong-gang in Gyeongsangnam-do, (4,201 in average), and followed by Geum-gang $(2,343)$, Nakdong-gang in Gyeongsangbuk-do $(1,623)$, Hangang $(1,564)$, Tamjin-gang $(1,550)$, Yeongsan-gang $(1,493)$, streams in the east coast $(1,028)$, Seomjin-gang (488) and Mangyeong-gang and Dongjin-gang (170) (Table 5). The prevalence in another species of rasborinid fish, $O$. uncirostris amurensis, was $74.8 \%$ (222 out of 297 fish examined) and their density was 278 per fish infected. On the other hand, Hong et al. [10] reported $86.8 \%$ and $78.5 \%$ prevalences in Z. platypus (164 out of 189 fish examined) and Z. temminckii (142 out of 181 fish examined), from 19 sites in the 6 major rivers of Korea. They also reported that densities with CaMc were more higher in $Z$. platypus (224 in average) than in Z. temminckii (131) [10]. In Hong et al. [10], the prevalences with CaMc in Zacco spp. were more or less different by the surveyed rivers, $60.6-100 \%$ (82.7\% in average), and their densities were most high in Nakdonggang (347 in average) and followed by Seomjin-gang (120), Tamjin-gang (59), Yeongsan-gang (44), Han-gang (29) and Geum-gang (27). The endemicities of CaMc in Zacco spp. in our study is much higher when we compared with those of Hong et al. [10]. However, the infection trend by fish species, more higher endemicity in $Z$. platypus than in Z. temminckii, is the same in Hong et al. [10]. Therefore, it appears that the endemicity of CaMc is currently much higher than in the past. It's reason why is obscure, but we can only suppose with general knowledges in the Parasitology textbook. Recently, the ecological conditions for this heterophyid fluke will be much better than in the past in Korea.

Chun [6] detected CaMc in 9 fish species, i.e., Z. platypus, $Z$. temminckii, P. altivelis, P. esocinus, P. parva, P. herzi, T. hakonensis, S. gracilis maejimae, $S$. japonicus coreanus, from the water systems of Nakdong-gang in Gyeongsangnam-do. Rhee et al. [8] found CaMc in 7 fish species, i.e., Aphyocypris chinensis, C. auratus, C. splendidus, Microphysogobio yaluensis, Rhodeus uyekii, $P$. parva and Z. platypus, from Mangyeong-gang and they also detected them in 5 fish species, i.e., Gnathopogon similis (=Squalidus intermedius), Pseudobagrus fulvidraco, P. parva, Rhodeus ocellatus ocellatus and Z. platypus, from Dongiin-gang [9]. Cho et al. [12] reported 15 fish species, i.e., A. rhombeus, A. signifier, $C$. herzi, G. brevibarba, H. longirostris, H. mylodon, K. rotundicaudata, L. andersoni, M. longidorsalis, O. uncirostris amurensis, Orthrias toni, P. esocinus, P. herzi, R. oxycephalus, and T. hakonensis, from the water systems of Gangwon-do as the new second intermediate hosts of $C$. armatus. Recently, Sohn et al. [13] detected CaMc in 5 fish species, Z. platypus, Z. temminckii, A. rhombeus, A. yamatsutae, and $A$. macropterus from the water systems of Hantangang and Imjin-gang. In this study, we found CaMc in total 44 fish species including 3 rasborinid fish, Z. platypus, Z. temminckii and $O$. uncirostris amurensis. Among them, 25 species were already reported in the previous studies [6-13]. Remain 19 species, i.e., A. springeri, A. gracilis, A. koreensis, A. majusculus, C. urotaenia, C. lutheri, C. kawamebari, G. strigatus, H. labeo, H. eigenmanni, M. salmoides, O. platycephala, O. masou masou, P. phoxinus, S. nigripinis morii, S. variegatus wakiyae and S. asotus, are to be the new second intermediate hosts of $C$. armatus in Korea. Accordingly, total 50 fish species (33 genera) are listed as the second intermediate hosts of C. armatus in Korea.

In the genus Centrocestus, the number of circumoral spines is considered to be the most reliable character in the species identification. C. armatus, having 42-48 circumoral spines, was 
first described by Tanabe [1] in Japan. Kobayashi [18] classified members in the genus Centrocestus into 4 groups on the basis of the number of circumoral spines. The group of C. yokogawai has less than 30 circumoral spines (26-30), C. formosanus has 32-40 ones, C. armatus has 42-48 ones, and C. polyspinosus has more than 50 ones (50-60) respectively. Among Centrocestus species with 42-48 circumoral spines, C. armatus is differentiated by characteristic morphological features include a small number of intrauterine eggs, the median location of the ovary, and the side by side location of the 2 testes $[2,20]$. On the other hand, Chai et al. [21] proposed to consider 6 species, i.e., $C$. cuspidatus, C. armatus, C. formosanus, C. kurokawai, C. polyspinosus, and $C$. asadai, in the genus Centrocestus as the valid ones.

In Korea, 3 species of Centrocestus fluke, i.e., C. armatus, $C$. asadai and $C$. formosanus, were reported in the literatures $[2,4$, 6,22,23]. Choi et al. [22] described C. asadai adults, which were recovered in the small intestines of mouse experimentally infected with the metacercariae from Tribolodon taczanowskii. Cho et al. [23] reported only the presence of $C$. formosanus cercariae in Korea. They found these cercariae from Semisulcospira libertina snails collected around the Jinyang-ho (ho means lake) in Gyeongsangnam-do, Korea. In regard to C. armatus, a lot of findings on the intermediate and definitive hosts were revealed by many Korean workers [2,4,6-17]. Adult worms were recovered from a human, the large egret (Egretta alba modesta) and stray cats (Felis catus) naturally infected [2,14-17]. Cercariae of this fluke were detected from Semisulcospira snails collected in Judongcheon in Dalseong-gun, Gyeongsangbuk-do [4]. Metacercarial infections were verified in the surveys of freshwater fish including Z. platypus and Z. temminckii [5-13]. Accordingly, we can know that $C$. armatus is predominant species in Korea and the presence of another 2 species, C. asadai and C. formosanus, is obscure, so there are no reports about those flukes since the first records [22,23].

Conclusively, it is confirmed that rasborinid fish, Z. platypus, $Z$. temminckii, and $O$. uncirostris amurensis, are highly and heavily infected with CaMc and the densities with CaMc are more or less different by the surveyed areas and fish species. Additionally, 19 fish species are to be the new second intermediate hosts of C. armatus in Korea.

\section{ACKNOWLEDGMENTS}

This study was supported by an anti-communicable diseases control program, 2013-0171 (Studies on the biological resourc- es of human infecting trematodes and their larval infections in intermediate hosts), 2014-E54002-00 (Investigation of fishborne parasites and acquisition of their biological resources in the southern regions of Korea) and 2015-E54001-00 (Investigation of fish-borne parasites and acquisition of their biological resources in the easthern regions of Korea) of National Institute of Health (NIH), Korea Centers for Disease Control and Prevention (KCDCP). This study was partly supported by a grant of Korea Association of Health Promotion (2017). We thank Jung-A Kim and Hee-Joo Kim (Department of Parasitology and Tropical Medicine, Gyeongsang National University College of Medicine, Jinju, Korea), for their help in the examination of fish.

\section{CONFLICT OF INTEREST}

The authors have no conflicts of interest concerning the work reported in this paper.

\section{REFERENCES}

1. Tanabe H. Studien uber die Trematoden mit Susswasser-fischen als Zwischenwirt. I. Stamnosoma armatum n. g., n. sp. Kyoto Igaku Zasshi 1922; 19: 239-252.

2. Hong SJ, Seo BS, Lee SH, Chai JY. A human case of Centrocestus armatus infection in Korea. Korean J Parasitol 1988; 26: 55-60.

3. Takahashi S. A contribution to the life-history of Stamnosoma armatum Tanabe. Okayama Igakkai Zasshi 1929; 41: 1759-1771.

4. Choi DW, Ahn DH, Kim HS. Larval trematodes from Semisulcospira snails in Kyungpook Province, Korea. Korean J Parasitol 1982; 20: 147-159.

5. Komiya Y. Metacercariae in Japan and adjacent territories. In Morishita K, Komiya Y, Matsubayashi H eds. Progress of Medical Parasitology in Japan. Vol. II. Tokyo, Japan. Meguro Parasitological Museum. 1965, pp 1-328.

6. Chun SK. Studies on some trematodes whose intermediate hosts are fishes in the Naktong river. Bull Fish Coll 1962; 4: 21-38 (in Korean).

7. Lee JT. Studies on the metacercariae from freshwater fishes in the Kum-Ho river. Korean J Parasitol 1968; 6: 77-99 (in Korean).

8. Rhee JK, Lee HI, Baek BK, Kim PG. Survey on encysted cercariae of trematodes from freshwater fishes in Mangyeong riverside area. Korean J Parasitol 1983; 21: 187-192 (in Korean).

9. Rhee JK, Rim MH, Baek BK, Lee HI. Survey on encysted cercaria of trematodes from freshwater fishes in Tongiin riverside areas in Korea. Korean J Parasitol 1984; 22: 190-202 (in Korean).

10. Hong SJ, Woo HC, Kim IT. Study on Centrocestus armatus in Korea I. Infection status of Zacco platypus and Z. temminckii with the metacercariae of C. armatus. Korean J Parasitol 1989; 27: 41-46 
(in Korean).

11. Sohn WM. Fish-borne zoonotic trematode metacercariae in the Republic of Korea. Korean J Parasitol 2009; 47 (suppl): 103-113.

12. Cho SH, Lee WJ, Kim TS, Seok WS, Lee T, Jeong K, Na BK, Sohn WM. Prevalence of zoonotic trematode metacercariae in freshwater fish from Gangwon-do, Korea. Korean J Parasitol 2014; 52: 399-412.

13. Sohn WM, Na BK, Cho SH, Lee SW, Choi SB, Seok WS. Trematode metacercariae in freshwater fish from water systems of Hantangang and Imjingang in Republic of Korea. Korean J Parasitol 2015; 53: 289-298.

14. Ryang YS, Ahn YK, Yoon MB. Trematode infections in the small intestine of Egretta alba medesta in Kangwon-do. Korean J Parasitol 1991; 29: 227-233 (in Korean).

15. Sohn WM, Chai JY. Infection status with helminthes in feral cats purchased from a market in Busan, Republic of Korea. Korean J Parasitol 2005; 43: 93-100.

16. Chai JY, Bahk YY, Sohn WM. Trematodes recovered in the small intestine of stray cats in the Republic of Korea. Korean J Parasitol 2013; 51: 99-106.

17. Shin SS, Oh DS, Ahn KS, Cho SH, Lee WJ, Na BK, Sohn WM. Zoonotic intestinal trematodes in stray cats (Felis catus) from riverside areas of the Republic of Korea. Korean J Parasitol 2015;
53: 209-213.

18. Kobayashi H. Reports of Scientifical works by H. Kobayashi. 1968. Studies on trematoda in Hainan Island, South China and Vietnam (French Indo China). pp 155-251.

19. Sohn WM. Trematodes. 1. Vol. 6. Incheon, Korea: The National Institute of Biological Resources; 2013. Invertebrate Founa of Korea; pp 1-125.

20. Hong SJ, Woo HC, Chai JY, Chung SW, Lee SH, Seo BS. Study on Centrocestus armatus in Korea. II. Recovery rate, growth and development of worms in albino rats. Korean J Parasitol 1989; 27: 47-56.

21. Chai JY, Sohn WM, Yong TS, Eom KS, Min DY, Lee MY, Lim H, Insisiengmay B, Phommasack B, Rim HJ. Centrocestus formosanus (Heterophyidae): human infections and the infection source in Lao PDR. J Parasitol 2013; 99: 531-536.

22. Choi DW, Shin DS, Lee SW. Studies on the larval trematodes from brackish water fishes: I. Observation of Centrocestus asadai Mishima, 1959. Korean J Parasitol 1964; 2: 14-19 (in Korean).

23. Cho HC, Chung PR, Lee KT. Distribution of medically important freshwater snails and larval trematodes from Parafossarulus manchouricus and Semisulcospira libertina around the Jinyang Lake in Kyongsang-Nam-Do, Korea. Korean J Parasitol 1983; 21: 193204 (in Korean). 

Supplementary Table S1. Infection status of CaMc in Opsariichthys uncirostris amurensis from the water systems of Korea

\begin{tabular}{|c|c|c|c|c|}
\hline \multirow{2}{*}{ Locality (year) } & \multirow{2}{*}{$\begin{array}{l}\text { No. of fish } \\
\text { examined }\end{array}$} & \multirow{2}{*}{$\begin{array}{l}\text { No. (\%) of fish } \\
\text { infected }\end{array}$} & \multicolumn{2}{|c|}{ No. of CaMc detected } \\
\hline & & & Range & Average \\
\hline Suipcheon (2009) & 5 & $1(20.0)$ & - & 3 \\
\hline Hongcheon-gang (2010) & 2 & $2(100)$ & $1,460-2,290$ & 1,875 \\
\hline Cheonnae-gang (2013-2015) & 4 & $4(100)$ & $12-562$ & 255 \\
\hline Yugucheon $(2013,2015)$ & 18 & $18(100)$ & $182-5,240$ & 871 \\
\hline Nonsancheon (2013) & 7 & $2(28.6)$ & $1-2$ & 2 \\
\hline Soyangcheon (2013) & 1 & $1(100)$ & - & 2 \\
\hline Osucheon (2012) & 21 & $16(76.2)$ & $3-35$ & 11 \\
\hline Seomjin-gang in Sunchang $(2014,2015)$ & 14 & $14(100)$ & $8-976$ & 153 \\
\hline Seomjin-gang in Gurye (2014) & 13 & $13(100)$ & $103-631$ & 301 \\
\hline Naeseongcheon in Yecheon $(2008,2013)$ & 19 & $14(74.0)$ & $1-203$ & 32 \\
\hline Yeonggang (2009) & 7 & $7(100)$ & $12-50$ & 30 \\
\hline Nakdong-gang in Andong (2009) & 8 & $8(100)$ & $2-973$ & 130 \\
\hline Namdaecheon in Uiseong (2009) & 10 & $9(90.0)$ & $2-34$ & 12 \\
\hline Wicheon $(2008,2015,2016)$ & 10 & $10(100)$ & $24-748$ & 305 \\
\hline Hoecheon (2013) & 10 & $1(10.0)$ & - & 2 \\
\hline Jisucheon (2014) & 4 & $4(100)$ & $64-728$ & 352 \\
\hline Hamancheon (2014) & 23 & $13(56.5)$ & $1-26$ & 4 \\
\hline Hyeongsan-gang (2015) & 3 & $3(100)$ & $41-446$ & 222 \\
\hline Taehwa-gang (2015) & 10 & $2(20.0)$ & $3-7$ & 5 \\
\hline Total & 292 & $217(74.3)$ & $1-4,480$ & 284 \\
\hline
\end{tabular}


Supplementary Table S2. Fish species with CaMc except for the rasborinid fish in the present study

\begin{tabular}{|c|c|}
\hline Fish species & Locality (year examined) \\
\hline Abbottina springeri & Seomjin-gang in Sunchang (2014) \\
\hline Acanthorhodeus gracilis & $\begin{array}{l}\text { Naeseongcheon in Yecheon (2008); Osucheon (2012); Seomjin-gang in Gurye (2014) \& Sunchang (2014, 2015); } \\
\text { Cheokgwacheon (2015); Cheonnae-gang (2015); Soyangcheon (2015); Wicheon (2017); Yangcheon (2017) }\end{array}$ \\
\hline Acanthorhodeus macropterus & Yangcheon (2010); Hoecheon (2013); Hantan-gang (2014); Hyeongsan-gang (2015); Soyangcheon (2015) \\
\hline Acheilognathus koreensis & Hantan-gang (2014); Hoengcheon (2014); Wicheon (2014, 2015); Jicheon (2014); Seomjin-gang in Sunchang (2015) \\
\hline Acheilognathus lanceolatus & Tamjin-gang (2014): Yugucheon (2015) \\
\hline Acheilognathus majusculus & Yangcheon (2014) \\
\hline Acheilognathus rhombeus & $\begin{array}{l}\text { Yangcheon (2010, 2017); Hantan-gang (2012, 2014); Wicheon (2014, 2015); Seomjin-gang in Gurye (2014); } \\
\text { Osipcheon in Yeongduk (2015); Cheokgwacheon (2015); Yugucheon (2015); Seomjin-gang in Sunchang (2015); } \\
\text { Tamjin-gang (2015, 2017) }\end{array}$ \\
\hline Acheilognathus signifier & Hantan-gang (2010) \\
\hline Acheilognathus yamatsutae & Wicheon (2013, 2014, 2015); Yangcheon (2017) \\
\hline Carassius auratus & Hantan-gang (2010); Wicheon (2015); Cheokgwacheon (2015); Yangcheon (2017) \\
\hline Chaenogobius urotaenia & Osipcheon in Samcheok (2015) \\
\hline Cobitis lutheri & Wicheon (2017) \\
\hline Coreoleuciscus splendidus & Hongcheon-gang (2010); Pyeongchang-gang (2013); Banbyeoncheon (2015) \\
\hline Coreoperca herzi & $\begin{array}{l}\text { Hongcheon-gang (2010); Yangcheon (2010, 2015); Choyang-gang (2012); Wicheon (2014); Seomjin-gang in Gurye } \\
\text { (2014) \& Gokseong (2015) }\end{array}$ \\
\hline Coreoperca kawamebari & Tamjin-gang $(2015,2017)$ \\
\hline Gnathopogon strigatus & Songdaecheon (2012); Seomjin-gang in Sunchang $(2014,2015) ;$ \\
\hline Gobiobotia brevibarba & Hantan-gang (2013) \\
\hline Hemibarbus labeo & Wicheon (2016) \\
\hline Hemibarbus longirostris & $\begin{array}{l}\text { Hongcheon-gang (2010); Yangcheon (2010, 2015); Hantan-gang (2012, 2013); Naeseongcheon in Yecheon (2014); } \\
\text { Cheonna-gang (2014); Soyangcheon (2014, 2015); Yugucheon (2015); Seomjin-gang in Sunchang (2015); Tamjin- } \\
\text { gang (2017) }\end{array}$ \\
\hline Hemibarbus mylodon & Pyeongchang-gang (2013) \\
\hline Hemiculter eigenmanni & Tamjin-gang (2014) \\
\hline Koreocobitis rotundicaudata & Choyang-gang (2012) \\
\hline Ladislabia taczanowskii & Osipcheon in Samcheok (2015) \\
\hline Liobagrus andersoni & Choyang-gang (2012) \\
\hline Microphysogobio longidorsalis & Hantan-gang (2012, 2013); Pyeongchang-gang (2013) \\
\hline Micropterus salmoides & Tamjin-gang (2014): Taehwa-gang (2015); Yangcheon (2017) \\
\hline Odontobutis platycephala & Yangcheon (2010, 2013); Wicheon (2014, 2016); Hyeongsan-gang (2015); Soyangcheon (2015) \\
\hline Onchorhynchus masou masou & Namdaecheon in Yangyang (2015); Osipcheon in Samcheok (2015) \\
\hline Phoxinus phoxinus & Osipcheon in Samcheok (2015) \\
\hline Plecoglossus altivelis & Namdaecheon in Yangyang (2015); Osipcheon in Samcheok (2015) \\
\hline Pseudogobio esocinus & $\begin{array}{l}\text { Wicheon (2008); Yeong-gang (2009); Yangcheon (2010); Hantan-gang (2012, 2014); Choyang-gang (2012); Pyeong- } \\
\text { chang-gang (2013); Yugucheon (2013); Yangcheon (2013, 2017); Jisucheon (2014); Jicheon (2014); Seomjin-gang } \\
\text { in Gurye (2014) \& Sunchang (2015); Cheonnae-gang (2015); Soyangcheon (2015); Namsancheon (2016) }\end{array}$ \\
\hline Pseudorasbora parva & Seomjin-gang in Gurye (2014) \\
\hline Pungtungia herzi & $\begin{array}{l}\text { Bukcheon in Sangju (2008); Hongcheon-gang (2010); Yangcheon (2013, 2016, 2017); Hantan-gang (2014); } \\
\text { Namdaecheon in Yangyang (2015); Wangpicheon (2015); Wicheon (2017) }\end{array}$ \\
\hline Rhodeus ocellatus & Hantan-gang (2013); Osucheon (2013) \\
\hline Rhynchocypris oxycephalus & $\begin{array}{l}\text { Osipcheon in Samcheok (2009, 2015); Namdaecheon in Yangyang (2015); Wicheon (2015); Cheokgwacheon (2015); } \\
\text { Taehwa-gang (2015) }\end{array}$ \\
\hline Sarcocheilichthys nigripinis & Wicheon (2017) \\
\hline Sarcocheilichthys variegatus & Soyangcheon (2013); Seomjin-gang in Sunchang (2015) \& Gokseong (2015) \\
\hline Silurus asotus & Baekcheon (2009) \\
\hline Squalidus gracilis maejimae & Osipcheon in Yeongdeok (2008); Seomjin-gang in Sunchang (2015) \\
\hline Squalidus japonicus coreanus & Yangcheon (2013, 2017); Seomjin-gang in Sunchang (2015) \& Gokseong (2015); Wicheon (2017) \\
\hline Tribolodon hakonensis & Namdaecheon in Yangyang (2009, 2015); Osipcheon in Samcheok (2015); Wangpicheon (2015) \\
\hline
\end{tabular}

